\title{
Olive (Olea Europaea L.): Southern-Italian Biodiversity Assessment and Traceability of Processed Products by Means of Molecular Markers
}

\author{
V. Alba ${ }^{1}$, W. Sabetta ${ }^{1}$, C. Summo ${ }^{2}$, F. Caponio ${ }^{2}$, \\ R. Simeone ${ }^{1}$, A. Blanco ${ }^{1}$, A. Pasqualone ${ }^{2}$ and C. Montemurro ${ }^{1}$ \\ ${ }^{1}$ Department of Agro-forestry and Environmental Biology and Chemistry, \\ ${ }^{2}$ Section of Genetics and Breeding and Section of Food Science and Technology, \\ University of Bari, \\ Italy
}

\section{Introduction}

Southern Italy has geographical, climatic, historical and traditional peculiarities summarized in a landscape to which olive trees are the backdrop. Olive (Olea europaea L. subsp. europaea) is cultivated since the third millennium B.C. in the Eastern region of the Mediterranean sea (Loukas \& Krimbas, 1983) and spread later around the basin following land and maritime routes to Italy, Spain, North Africa and France (Angiolillo et al., 1999).

The plant longevity, the cross-pollinating nature of the species and its secular history contributed to determine a wide germplasm biodiversity with more than 1200 cultivars, 9.992 thousand harvested hectares and a total production of 18 million tons (Tab.1; FAO 2009) mostly concentrated in the main olive oil producing countries (Alba et al., 2009a). Europe alone produces the $69 \%$ of the total worldwide production (Fig. 1). Italy is one of the main producers and has a rich assortment of olive cultivars, with a total number of 395 registered entries in the national list of O. europaea L. Italian cultivars (Official Journal of the Italian Republic, 1994), covering 1,18 million hectares and a total production of 3.6 million tons (ISTAT, 2010). The $80 \%$ of the cultivation is mostly concentrated in Southern Italy, where the production touches the $88 \%$ of the whole Italian olive production. In particular, Apulia region alone produces $1 / 3$ of the total (about 1,7 milion tons) (Tab. 2).

Nowadays olive-growing has a crucial commercial role in many Italian regions with a richness of biodiversity spread from North to South in terms of cultivars grown, agronomic practices, processes of transformation of the raw material. Therefore, the preservation and protection of Italian olive biodiversity depends upon the use of genetic research tools like molecular markers for a correct cultivar identification. In countries that belong to the "Union Internationale pour la Protection des Obtentions Végetales" (UPOV) the registration, multiplication, certification, and commercialization of olive varieties rely on the evaluation of morpho-agronomic descriptors. Recently, morphological, biochemical and agronomic traits have been complemented with the large array of DNA molecular marker types 
available, that provide an accurate and unambiguous tool for a correct identification of cultivated olive germplasm. Corrado et al. (2009) report that morpho-agronomic analyses on quantitative data in olive often are in contrast to DNA molecular analyses. Despite this, the authors consider the use of morpho-agronomical descriptors irreplaceable for the description of local or neglected olive cultivars since they are simple to be recorded and focus on important agronomic traits, while an accurate and unambiguous olive cultivars identification cannot be performed without the use of molecular markers.

In these last years the Department of Agro-forestry and Environmental Biology and Chemistry of the University of Bari (DiBCA) employed molecular markers both for olive cultivar identification and olive oil traceability. Amplified fragment Polymorphism (AFLP), in absence of sequence information about the olive genome, have been largely employed for simultaneous screening of a large number of loci with high efficiency in revealing inter and intra-cultivar variability (Angiolillo et al., 1999; Belaj et al., 2003; Grati-Kamoun et al., 2006; Montemurro et al., 2005; Montemurro et al., 2008; Sensi et al., 2003). Also Inter Simple Sequence Repeats (ISSR) have been efficiently employed for cultivar identification of olive (Pasqualone et al., 2001). As sequences of genomic DNA in olive became available, Simple Sequence Repeats (SSR) have become the markers of choice for varietal identification studies as they are transferable, hypervariable, highly polymorphic, multiallelic, polymerase chain reaction (PCR)-based co-dominant markers. They are relatively simple to interpret and show a high information content (Ganino et al., 2006). In fact, SSR result less laborious and cheaper than AFLP and do not require special equipment and manipulation of radiolabelled substances, making possible to transfer SSR protocols for routine analyses. Recently, several olive SSRs have been published (Carriero et al., 2002; Cipriani et al., 2002; De la Rosa et al., 2002; Diaz et al., 2006; Sefc et al., 2000) and screened on a huge number of cultivars. The most part of these SSR have been evaluated by Baldoni et al. (2009) on a set of 77 cultivars from different geographical origins. The authors provided details on reproducibility, power of discrimination and number of amplified loci/alleles and precise band size alleles, indicating the most suitable SSR markers for olive cultivar identification. The allele sequencing makes it possible to have a reference point when screening olive cultivars with SSR, since the right size dimension of SSR alleles represents a bottleneck when phenomena of stuttering or genotyping errors occurr. Further information on olive germplasm, cultivar names, homonyms and synonims, SSR data and Expressed Sequence Tag (EST) are available at Oleadb database (www.Oleadb.it).

The advantages enfisized for SSR are much more justified by their applicability on processed material since significant amounts of DNA, suitable for PCR analysis, are present in residues from olive oil mechanic extraction (Alba et al., 2009b; Breton et al., 2004; Consolandi et al., 2008; de la Torre et al., 2004, Montemurro et al., 2008; Pasqualone et al., 2004a; 2004b).

Extra-virgin olive oil represent the pride of the Italian olive production and is only obtained by mechanical or physical extraction with any chemical change. It must fufil a series of physicchemical quality parameters, such as a free acidity below $0.8 \mathrm{~g} / 100 \mathrm{~g}$ expressed in free oleic acid content (Commission Regulation EU No 61/2011). For its fatty acid composition, with a high monounsaturated - to - polyunsaturated fatty acid ratio and the presence of minor compounds having anti-oxidant activity, extra-virgin olive oil is especially appreciated for its high resistance to oxidative deterioration, playng a crucial role in the so called Mediterranean diet (Bendini et al., 2007; Harwood and Yaqoob, 2002; Visioli and Galli, 2002). 


\begin{tabular}{lcc}
\hline & $\begin{array}{c}\text { Area Harvested } \\
\text { (thousand Ha) }\end{array}$ & $\begin{array}{c}\text { Total Production } \\
\text { (million tons) }\end{array}$ \\
\hline Albania & 40,0 & 0,05 \\
Algeria & 288,4 & 0,48 \\
Croatia & 15,3 & 0,03 \\
Cyprus & 12,0 & 0,01 \\
Egypt & 110,0 & 0,50 \\
France & 19,0 & 0,03 \\
Greece* & 800,0 & 2,31 \\
Israel & 16,0 & 0,03 \\
Italy & $1.159,0$ & 3,60 \\
Jordan & 60,7 & 0,14 \\
Libya* & 0,2 & 0,18 \\
Morocco & 550,0 & 0,77 \\
Portugal & 380,7 & 0,36 \\
Spain & $2.500,0$ & 6,20 \\
Syrian & 635,7 & 0,89 \\
Tunisia & $2.300,0$ & 0,75 \\
Turkey & 727,5 & 1,29 \\
World & $9.922,8$ & $\mathbf{1 8 , 2 4}$ \\
Europe & $4.923,2$ & 12,61 \\
Northern Africa & $3.248,6$ & 2,68 \\
Western Asia & $1.604,0$ & 2,54 \\
Others & 146,9 & 0,42 \\
\hline
\end{tabular}

Table 1. Area harvested and total olive production in the main producing countries of the Mediterranean Bacin and in the main worldwide geographical productive areas. (FAO, 2009). * Data are referred to 2008.

\begin{tabular}{lcccc}
\hline & \multicolumn{2}{c}{$\begin{array}{c}\text { Italian total area } \\
\text { allocated to olive }\end{array}$} & \multicolumn{2}{c}{$\begin{array}{c}\text { Total olive production } \\
\text { (table, oil, double purpose) }\end{array}$} \\
\hline & thousand ha & \% on the total area & million tons & \% on the total production \\
\hline Northern Italy & 28,4 & 2,4 & 0,49 & 1,4 \\
Central Itali & 205,2 & 17,3 & 3,88 & 10,7 \\
Southern Italy & 949,8 & 80,3 & 31,75 & 87,9 \\
Total & $\mathbf{1 1 8 3 , 4}$ & & $36, \mathbf{1 1}$ & \\
& & & & \\
Apulia region & 377,6 & 39,8 & 11,72 & 36,9 \\
Other Southern regions & 572,2 & 60,2 & 20,03 & 63,1 \\
\hline
\end{tabular}

Table 2. Consistency of the Italian olive cultivation (ISTAT, 2010) 
Unique sensorial, aromatic, gustatory, nutraceutical and healthy properties of the different Italian extra-virgin olive oil justify the attention devoted to the respect of standard parameters of quality all along the productive chain.

The skill developed by olive growers after centuries of cultivation has led Italy to become one of the first producing countries of olive oil considering the ratio between quality and quantity. In order to guarantee, preserve and promote the both the olive genetic variability and the technical expertise in cultivating, collecting and transforming processes of olives, Italian producers consortiated and obtained marks of protected designation of origin (PDO) at European level according to EC Regulation no. 510/06. An official production protocol of any PDO extra-virgin olive oil must meet a specific varietal requirement alone or in combination with other varieties eventually allowed by the protocol at well defined percentages. Therefore, it is clear that traceability, of raw and processed materials, specially by means of molecular markers, assumes a crucial role in the certification of products for the protection of consumers and for fraud prevention.

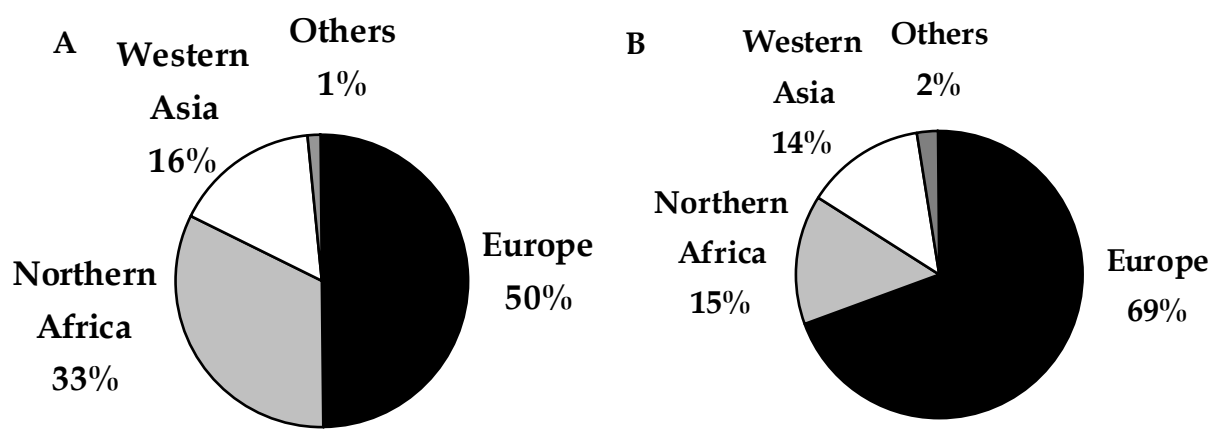

Fig. 1. Percentage distribution of harvested area (A) and total olive production (B) in the main worldwide geographical productive areas. (FAO, 2010).

The aim of this paper is to review the research activity conducted in the last decade by the DiBCA in the fields of Southern Italian olive cultivar identification and monovarietal olive oil traceability (tab. 3, tab. 4). To this purpose, only certified material from the Experimental Station "P. Martucci" of the Plant Production Department (D.P.V.) and the DiBCA, from the Nursery "Vivai Giannoccaro" in Bari-Italy, from the Olive Pre-multiplication Centre "Concadoro" in Palagiano - Italy and from the Department of Olive Research, Idleb, Syria was analysed.

\section{Molecular markers for olive cultivar identification and monovarietal olive oil traceability}

\subsection{ISSR markers}

ISSR are DNA based markers that involve amplification via polymerase chain reaction (PCR) of DNA regions situated between adjacent and inversely oriented 16-18 bp long simple sequence repeats, already employed successfully for cultivar identification purposes. ISSR, together with physico-chemical analyses, were used for olive cultivar identification in 2001 by Pasqualone et al.. Here we focus on the molecular aspect of that paper. In particular, 10 olive cultivars were screened with 10 ISSR markers. DNA was extracted from fresh leaves 


\begin{tabular}{|c|c|c|c|c|c|}
\hline $\begin{array}{l}\text { Molecular } \\
\text { marker } \\
\text { class }\end{array}$ & $\begin{array}{l}\text { Matrix for } \\
\text { DNA } \\
\text { extraction }\end{array}$ & $\begin{array}{c}\mathrm{N}^{\circ} \\
\text { Markers } \\
\text { tested }\end{array}$ & $\begin{array}{c}\mathrm{N}^{\circ} \\
\text { Olive } \\
\text { cultivars }\end{array}$ & $\begin{array}{l}\text { Minimum } n^{\circ} \text { of } \\
\text { markers } \\
\text { distinguishing } \\
\text { cultivars }\end{array}$ & Source \\
\hline ISSR & $\begin{array}{c}\text { Leaves } \\
\text { Drupes } \\
\text { Virgin oil }\end{array}$ & 10 & 10 & 2 & $\begin{array}{c}\text { Pasqualone et } \\
\text { al., } 2001\end{array}$ \\
\hline SSR & $\begin{array}{c}\text { Leaves } \\
\text { Virgin oil }\end{array}$ & 10 & 5 & 2 & $\begin{array}{l}\text { Pasqualone et } \\
\text { al., } 2003\end{array}$ \\
\hline SSR & $\begin{array}{c}\text { Leaves } \\
\text { Drupes } \\
\text { Virgin oil }\end{array}$ & 7 & 10 & 3 & $\begin{array}{c}\text { Pasqualone et } \\
\text { al., 2004a }\end{array}$ \\
\hline SSR & $\begin{array}{c}\text { Leaves } \\
\text { Virgin oil }\end{array}$ & 4 & 2 & 1 & $\begin{array}{c}\text { Pasqualone et } \\
\text { al., 2004b }\end{array}$ \\
\hline $\begin{array}{l}\text { AFLP } \\
\text { SSR }\end{array}$ & Leaves & $\begin{array}{c}3 \\
27\end{array}$ & 60 & - & $\begin{array}{l}\text { Montemurro } \\
\text { et al., } 2005\end{array}$ \\
\hline SSR & Virgin oil & 7 & 7 & - & $\begin{array}{c}\text { Pasqualone et } \\
\text { al., 2007a }\end{array}$ \\
\hline SSR & $\begin{array}{c}\text { Leaves } \\
\text { Virgin oil }\end{array}$ & 1 & 75 & - & $\begin{array}{c}\text { Pasqualone et } \\
\text { al., 2007b }\end{array}$ \\
\hline SSR & Leaves & 4 & 9 & - & $\begin{array}{c}\text { Alba et al., } \\
2008\end{array}$ \\
\hline AFLP & $\begin{array}{c}\text { Leaves } \\
\text { Virgin oil }\end{array}$ & 6 & 10 & 1 & $\begin{array}{l}\text { Montemurro } \\
\text { et al., 2008a }\end{array}$ \\
\hline $\begin{array}{c}\text { SSR } \\
\text { AFLP }\end{array}$ & Leaves & $\begin{array}{c}27 \\
3\end{array}$ & 37 & - & $\begin{array}{l}\text { Montemurro } \\
\text { et al., 2008b }\end{array}$ \\
\hline SSR & Leaves & 16 & 30 & 2 & $\begin{array}{c}\text { Alba et al., } \\
\text { 2009a }\end{array}$ \\
\hline SSR & $\begin{array}{c}\text { Leaves } \\
\text { Virgin oil }\end{array}$ & 10 & 7 & 1 & $\begin{array}{l}\text { Alba et al., } \\
\text { 2009b }\end{array}$ \\
\hline
\end{tabular}

Table 3. Cultivar identification and olive oil traceability research activities conducted at the Department of Agro-forestry and Environmental Biology and Chemistry, University of Bari, Italy.

and ripe drupes following the protocol proposed by Sharp et al. (1988) with some modifications. Monovarietal olive oil was obtained by mechanical extraction with the method proposed by Catalano \& Caponio (1996) and, after centrifugation of $250 \mathrm{ml}$ oil, the cell residue sediment was recovered and used for the DNA extraction with the same protocol of leaves and drupes. DNA extracted from leaves and drupes was rich in PCR interfering substances such as phenolic compounds and lipids, suggesting a further purification achieved by chromatography on a commercial device. On the contrary, the DNA extraction protocol revealed to be inadequate when processing cell residue sediments, yielding degraded or unsuitable for PCR experiments (i.e. all 10 ISSR primers failed to amplify). Three ISSR completely failed to amplify both on leaf and drupe DNA, while 7 ISSR gave distinguishable electrophoretic patterns with appreciable polymorphic content, so that a set-up of an identification key with the lowest number of molecular markers that distinguish among the 10 cultivars was obtained by means of only 2 ISSR. The paper 


\begin{tabular}{|c|c|c|c|}
\hline Olive cultivar & Molecular marker class & Olive cultivar & $\begin{array}{l}\text { Molecular } \\
\text { marker class }\end{array}$ \\
\hline Aglandau & AFLP, SSR & Manzanilla & AFLP, SSR \\
\hline Ascolana Tenera & AFLP, SSR & Maurino & AFLP, SSR \\
\hline Atena & AFLP, SSR & Mele & AFLP, SSR \\
\hline Bella di Cerignola & AFLP, SSR & Mora & AFLP, SSR \\
\hline Bella di Spagna & AFLP, SSR & Moraiolo & AFLP, ISSR, SSR \\
\hline Bouteillan & AFLP, SSR & Nocellara del Belice & AFLP, SSR \\
\hline Canino & AFLP, SSR & Nocellara Etnea & AFLP, SSR \\
\hline Carolea & AFLP, SSR & Nocellara Messinese & AFLP, SSR \\
\hline Cassanese & ISSR & Nociara & AFLP, ISSR, SSR \\
\hline Cazzinicchio & AFLP, SSR & Nolca & AFLP, SSR \\
\hline Cellina di Nardò & AFLP, ISSR, SSR & Ogliarola barese & AFLP, SSR \\
\hline Cerasella & AFLP, SSR & Ogliarola garganica & SSR \\
\hline Cima di Bitonto & AFLP, ISSR, SSR & Ogliarola salentina & ISSR, SSR \\
\hline Cima di Mola & SSR & Oliastro & AFLP, SSR \\
\hline Cima di Melfi & AFLP, SSR & Oliva rossa & SSR \\
\hline Cipressino & SSR & Pasola & AFLP, SSR \\
\hline Conservolia & AFLP, SSR & Pasola di Andria & AFLP, SSR \\
\hline Coratina & AFLP, ISSR, SSR & Pendolino & AFLP, SSR \\
\hline Corniola & SSR & Peppino & AFLP, SSR \\
\hline Dolce di Cassano & AFLP, SSR & Peranzana & AFLP, SSR \\
\hline $\begin{array}{l}\text { Dolce di } \\
\text { Montescaglioso }\end{array}$ & AFLP, SSR & Picholine & AFLP, SSR \\
\hline Donna Francesca & SSR & Picual & AFLP, SSR \\
\hline Donna Giulietta & SSR & Primicea & AFLP, SSR \\
\hline Frantoio & AFLP, SSR & S. Agostino & AFLP, SSR \\
\hline Gentile di Larino & ISSR & S. Caterina & AFLP, SSR \\
\hline Giarraffa & AFLP, SSR & S. Francesco & AFLP, SSR \\
\hline Gioconda & AFLP, SSR & Simone & AFLP, SSR \\
\hline Grignan & AFLP, SSR & Selvatic entry & AFLP, SSR \\
\hline Grossane & AFLP, SSR & Sigoise & AFLP, SSR \\
\hline Itrana & AFLP, ISSR, SSR & Tanche & AFLP, SSR \\
\hline Kalamata & AFLP, SSR & Termite di Bitetto & AFLP, SSR \\
\hline Leccino & AFLP, ISSR, SSR & Tonda Iblea & AFLP, SSR \\
\hline Leccio del Corno & AFLP, SSR & Toscanina & AFLP, SSR \\
\hline Leo & AFLP, SSR & Verdale & AFLP, SSR \\
\hline Maiatica & AFLP, SSR & Vergiola & AFLP, SSR \\
\hline
\end{tabular}

Table 4. List of the olive cultivars screened by means of AFLP, ISSR and SSR at the DiBCA

concluded that ISSR represent a powerful tool to distinguish among olive cultivars but revealed an important aspect in relation to the establishment of more accurate protocols to be used for DNA extraction from cell residue sediments of olive oil. A robust and efficient 
method for extracting DNA from olive oil is a prerequisite for developing a platform of marker-based assessment of olive oil cultivar composition (Consolandi et al, 2008). Today, many commercial kits to extract DNA from processed food are available and help researchers to overcome the problem.

\subsection{AFLP markers}

AFLP markers (Vos et al., 1995) allow multi-locus screening of a genome in absence of preliminary sequence knowledge. The use of AFLP for olive cultivar identification and oil traceability has been described before. In particular, Montemurro et al. (2005) tested 3 AFLP primer combinations and 27 SSR (discussed later) on a set of 60 olive cultivars, some of them present in replicates and coming from different germplasm collections, for a total of 112 samples, from the Mediterranean basin. DNA was extracted from lyophilized leaves with the commercial Gene Elute Plant kit and a biodiversity study was conducted. A dendrogram of genetic similarity based on Jaccard index (1901) was calculated with NTSYS-PC (Rohlf, 1992) using AFLP and SSR data. All the cultivars resulted distinguished and clustered according to their type of use: oil, table, and dual purpose cultivars. Differences between the two techniques were detected. The ratio of polymorphic bands/total bands ranged from a maximum of $100 \%$ for SSRs to $42 \%$ for AFLP, in line with other authors (Belaj et al., 2003; Powell et al., 1996; Russell et al., 1997) that confirmed the higher efficiency of SSR to distinguish among olive cultivars, but revealed the ability of AFLP to distinguish intravarietal clones respect to SSR. Therefore, AFLP represent the best choice for studies into genetic relationship or for accurate evaluation of intra-cultivar variability.

Based on this experience, the authors hypothesized and wanted to verify the effectiveness of AFLP in distinguishing among oils from different cultivars. To this purpose, Montemurro et al. (2008) tested the efficiency of AFLP on 10 different virgin oils. Oils were obtained with a laboratory-scale pilot plant consisting of a SK1 hammer-crusher (Retsch, Haan, Germany) and $200 \mathrm{ml}$ were centrifuged to recover residues. In this case, in order to overcome problems of DNA of low quality encountered in the past, the commercial Gene Elute Plant kit (Sigma) to extract DNA from cell residue sediments and lyophilized leaves was adopted. All the 6 AFLP primer combination yielded polymorphic electrophoretic patterns for all the 10 cultivars both for leaf and oil DNA. The level of degradation, the low DNA concentration extractable from oil and the template needed by the restriction enzymes for the initial digestion (100 ng) in the AFLP method suggested a standard protocol implementation in case of DNA from oil (Montemurro et al., 2005). Specifically, no dilution of both restricted/ligated and preamplified products were performed before selective amplifications, on the contrary $30 \mu \mathrm{l}$ of restricted/ligated product, much higher than usual, was used for ensuring good amounts of DNA template. Differences about the band intensity emerged for the amplicons of DNA from oil, reducing the number of scorable bands after electrophoresis, but showing sufficient information useful for olive oil traceability.

\subsection{SSR markers}

As discussed before, SSR efficiency compared with other DNA-based markers in olive was demonstrated and nowadays they are preferred by several authors for biodiversity studies, germplasm characterization and varietal fingerprinting. Moreover, the recent introduction of fluorescent labeled primers that avoid radioactive labeled ones for PCR-based markers let the use of automatic sequencers, less time consuming and with minor health implications for operators. Besides, automatic sequencers are more effective, because capillary 
electrophoresis allows to distinguish alleles with very small differences in molecular weight, and has a higher resolutive power than classical methods. The sensibility of the method allows to evidence also weak signals, such as those that could come from olive oil DNA, known to be partially degraded (Alba et al., 2009b).

Baside AFLP analysis, Montemurro et al. (2005) started to screen 65 SSR on a sub-set ot an entire collection of 112 olive accessions. The goal was to select those SSR most efficiently employable in further studies of biodiversity and traceability in olive. Based on simplicity and reproducibility of electrophoretic patterns, 27 were chosen and analysed further on the entire set of olive accessions. Dendrograms of genetic similairity based on Jaccard index (1901) were calculated by means of NTSYS-PC (Rohlf, 1992) using AFLP and SSR data separately and combined. The analysis revealed the ability of AFLP to distinguish accessions belonging to the same cultivars. Conversly, SSR were not able to distinguish all the accessions, making necessary the combination with AFLP data for a complete distinction of all the accessions.

As described, the first attempts to amplify DNA from oil at the DiBCA by ISSR failed, suggesting a different molecular approach to the problem. The analysis of SSR at the DiBCA started in 2004 by Pasqualone et al.. DNA from leaves, drupes and virgin oil of 10 olive cultivars usually grown in Southern Italy were screened with 7 SSR. Virgin olive oil was obtained mechanically as reported before and the commercial Gene Elute Plant kit (Sigma) was used to extract DNA from all matrices. As expected, all the SSRs employed, resolved on agarose gel and ethidium bromide staining, yielded clear and reproducible electrophoretic patterns for leaves, drupes and virgin oil. Full correspondence of the alleles amplified was verified when comparing the electrophoretic profiles from the three different matrices of each olive cultivar. Three SSRs were used as a minimum number of molecular markers able to distinguish among the 10 olive cultivars.

These encouraging results and the standardization of DNA extraction and SSR amplification conditions led the DiBCA to verify the suitability of SSR for the traceability of a PDO extravirgin olive oil like "Collina di Brindisi" (Pasqualone et al., 2007a). Collina di Brindisi PDO is a typical Apulian olive oil (Tab. 5) prepared from Ogliarola (minimum 70\%), and other olive cultivars diffused in the production area alone or together, accounting for a maximum of $30 \%$, with no other indications of their single ratios (Official Journal Euopean. Community, 1996; Official Journal of the Italian Republic. 1998). The research consisted on the screening of different virgin oils, filtered and unfiltered, obtained by different oil mills and derived from the olive cultivars included in the disciplinary protocol. The screening was conducted both on monovarietal and binary blends. DNA was extracted by Gene Elute Plant kit (Sigma) and 7 SSR were employed to amplify DNA from different matrices. The suitability of the SSR technique in olive oil traceability was confirmed by the good amplification levels obtained both from cloudy unfiltered and from clear filtered oils. Sufficient cellular sediments for DNA extraction was obtained from filtered oils by augmenting starting oil volumes, centrifuging at higher speeds and for longer times respect to unfiltered oils, and improving the efficiency of the commercial kit used for DNA extraction by using higher amounts of the extracting reagents. The interesting aspect of this paper was represented not only by the fact that SSR confirmed the composition of a certain olive oil, but GAPU89 discovered a wrong designation attributed by one of the mills that provided the experimental material. In particular, an oil supposed to be composed by Leccino was verified to be composed by Ogliarola. Moreover, the paper tried to shed light on the cultivar "Ogliarola", registered in the national list of O. europaea Italian cultivars 
(Official Journal of the Italian Republic. 1998). In Apulia region at least 3 different type of Ogliarola, namely barese, salentina, and garganica, derive their qualifications from the three different geographical districts of diffusion. The SSR GAPU 89 confirmed the assumption, due to geographical aspects, of the identity of the generic Ogliarola with Ogliarola salentina, since its intense cultivation with respect to the other two in the production area of the "Collina di Brindisi" PDO oil. Infact, Ogliarola garganica e Ogliarola barese showed different electrophoretic pattern between them and with respect to Ogliarola salentina, which showed monomorphic pattern when compared to Ogliarola profile (Tab. 6). Beside this, the allelic profile of "Ogliarola" was detectable also in the binary blends, providing a qualitative result of a product. Its prevailing in Collina di Brindisi PDO oil in amounts higher than $70 \%$ could be used as a positive control, since the absence of the Ogliarola salentina pattern in a commercial Collina di Brindisi PDO oil could be revealed to be a fraud.

In Apulia region, Southern Italy, five extra-virgin olive oil bear the PDO mark of quality (Tab. 5). Besides the "Collina di Brindisi", "Terra di Bari" represents one of the most produced PDO oils in Apulia and can be subdivided into three distinct sub-denominations: "Bitonto", "Castel del Monte" and "Murgia dei Trulli e delle Grotte". In particular, the subdenomination "Bitonto" was focused by the DiBCA for traceability purposes by means of SSR (Alba et al., 2008a). The disciplinary of production of "Terra di Bari", sub-denomination "Bitonto" provides that this oil is obtained from the following varieties, present for at least $80 \%$, alone or in combination: Cima di Bitonto, Ogliarola barese or Coratina. These 3 cultivars were screened for allele biodiversity at 4 SSR loci together with other 6 cultivars diffused in Southern Italy and a dendrogram of genetic similarity based on Jaccard index was calculated (Fig. 2). Despite the low number of SSRs tested, all the cultivars were clearly distinguished, revealing a Jaccard value of at least 0.50 when comparing all the cultivars each other, except Cima di Mola e Ogliarola barese (Jaccard $=0.68$ ). More, table 7 shows the allelic profile at 3 SSR loci investigated on the cultivars comprised in the disciplinary of production of "Terra di Bari" and it is evident that all the SSR were singularly able to discriminate cultivars. The automation of the electrophoresis, conducted on a sequencer ABI PRISM 3100 Avant Genetic Analyzer, instead of agarose or PAGE gels, allowed a more precise read of the amplicons, revealing minimal differences between alleles differing by 2 bp. Fig. 3 provides a comparison between SSR amplification resolved on agarose gel and on automatic sequencer. As an example, samples amplified with DCA03 and run on sequencer revealed an allele at $237 \mathrm{bp}$ in Cima di Bitonto and at $239 \mathrm{bp}$ in Coratina, undistinguishable when resolved on agarose gel (data not shown).

Once established the efficiency of SSR in olive biodiversity assessment and in olive oil traceability, they have been largely used in the last years supplanting other more laborious and time-consuming molecular marker classes. Pasqualone et al. (2007b) presented a paper at the 3rd Commission Internationale du Genie Rural (CIGR) International Symposium held in Naples (September 24th - 26th) in which a set of 75 olive cultivars native from the Mediterranean basin and coming from different germplasm collections was subjected to SSR analysis with a DCA04 SSR locus, in order to provide a DNA-bank database. The choice of the SSR DCA04 (Sefc et al., 2000) employed in this paper was based on the simple repeat motif [(GA) $\left.{ }_{16}\right]$. Genotyping with di-nucleotide SSRs is difficult because separation from neighbourhood alleles requires very precise and reliable protocols for allele separation and identification to avoid allele misidentification (Baldoni et al., 2009). However, despite its dinucleotide nature, the SSR DCA04 revealed to be reliable in our previous SSR screening, in 


\begin{tabular}{|c|c|c|c|}
\hline $\begin{array}{l}\text { Italian PDO and IGP } \\
\text { extra-virgin olive oils }\end{array}$ & $\begin{array}{l}\text { O.J.I.R.* } \\
\text { legislative reference }\end{array}$ & $\begin{array}{l}\text { Italian } \\
\text { Region }\end{array}$ & $\begin{array}{l}\text { O.J.E.C.** } \\
\text { legislative reference }\end{array}$ \\
\hline Colline Teatine & O.J. $7.10 .1998, \mathrm{n}^{\circ} 234$ & Abruzzo & $\mathrm{n}^{\circ} 1065 / 97$ \\
\hline Aputino Pescarese & O.J. 20.8.1998, nº 193 & Abruzzo & $n^{\circ} 1263 / 96$ \\
\hline $\begin{array}{l}\text { Pretuziano delle Colline } \\
\text { Tramane }\end{array}$ & & Abruzzo & $n^{\circ} 1491 / 03$ \\
\hline Dauno & O.J. 20.8.1998, nº 193 & Apulia & $n^{\circ} 2325 / 97$ \\
\hline Terra d'Otranto & O.J. 20.8.1998, nº 193 & Apulia & $\mathrm{n}^{\circ} 1065 / 97$ \\
\hline Terra di Bari & O.J. 29.9.1998, $\mathrm{n}^{\circ} 227$ & Apulia & $n^{\circ} 2325 / 97$ \\
\hline Collina di Brindisi & O.J. 21.12.1998, n' 297 & Apulia & $n^{\circ} 1263 / 96$ \\
\hline Terre Tarentine & & Apulia & $\mathrm{n}^{\circ} 189 / 04$ \\
\hline Bruzio & O.J. $28.10 .1998, \mathrm{n}^{\circ} 252$ & Calabria & $n^{\circ} 1065 / 97$ \\
\hline Lametia & O.J. 11.11.1999, $\mathrm{n}^{\circ} 265$ & Calabria & $n^{\circ} 2107 / 99$ \\
\hline Alto Crotonese & O.J. 21.8.2003, $\mathrm{n}^{\circ} 193$ & Calabria & $n^{\circ} 1257 / 03$ \\
\hline Irpinia - Colline dell'Ufita & & Campania & $n^{\circ} 203 / 2010$ \\
\hline Cilento & O.J. 20.8.1998, nº 193 & Campania & $n^{\circ} 1065 / 97$ \\
\hline Penisola Sorrentina & O.J. 20.8.1998, nº 193 & Campania & $n^{\circ} 1065 / 97$ \\
\hline Colline Salernitane & G.U 11.9.2003, n 211 & Campania & $\mathrm{n}^{\circ} 1065 / 97$ \\
\hline Brisighella & O.J. 11.11.1998, n 264 & $\begin{array}{l}\text { Emilia } \\
\text { Romagna }\end{array}$ & $n^{\circ} 1263 / 96$ \\
\hline Colline di Romagna & O.J. 11.9.2003, $\mathrm{n}^{\circ} 211$ & $\begin{array}{l}\text { Emilia } \\
\text { Romagna }\end{array}$ & $n^{\circ} 149 / 03$ \\
\hline Canino & O.J. 11.11.1998, n 264 & Lazio & $n^{\circ} 1263 / 96$ \\
\hline Sabina & O.J. 20.6.1995, n' 142 & Lazio & $n^{\circ} 1263 / 96$ \\
\hline Riviera Ligure & O.J. 20.8.1998, nº 193 & Liguria & $n^{\circ} 123 / 97$ \\
\hline Molise & G.U 21.8.2003, ${ }^{\circ} 193$ & Molise & $n^{\circ} 1257 / 03$ \\
\hline Cartoceto & & Marche & $n^{\circ} 1897 / 04$ \\
\hline Laghi Lombardi & 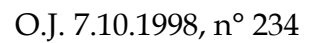 & Lombardy & $n^{\circ} 2325 / 97$ \\
\hline Garda & O.J. 7.10.1998, n' 234 & Lombardy & $n^{\circ} 2325 / 97$ \\
\hline Terra di Siena & O.J. 15.1.2001, $\mathrm{n}^{\circ} 11$ & Tuscany & $n^{\circ} 3446 / 00$ \\
\hline Chianti Classico & O.J. 17.1.2001, $\mathrm{n}^{\circ} 13$ & Tuscany & $\mathrm{n}^{\circ} 3446 / 00$ \\
\hline Lucca & & Tuscany & $\mathrm{n}^{\circ} 1845 / 04$ \\
\hline Toscano & & Tuscany & $n^{\circ} 644 / 98$ \\
\hline Tuscia & & Tuscany & $n^{\circ} 1623 / 05$ \\
\hline Umbria & & Umbria & $n^{\circ} 2325 / 97$ \\
\hline Veneto & O.J. 15.11.2001, $\mathrm{n}^{\circ} 266$ & Veneto & $n^{\circ} 2036 / 01$ \\
\hline Val di Mazara & O.J. 28.3.2001, $\mathrm{n}^{\circ} 73$ & Sicily & $\mathrm{n}^{\circ} 138 / 01$ \\
\hline Valli Trapanesi & O.J. $26.10 .1998, \mathrm{n}^{\circ} 250$ & Sicily & $\mathrm{n}^{\circ} 2325 / 97$ \\
\hline Monti Iblei & O.J. $24.10 .1998, n^{\circ} 249$ & Sicily & $n^{\circ} 2325 / 97$ \\
\hline Valdemone & & Sicily & $n^{\circ} 205 / 05$ \\
\hline Monte Etna & O.J. 21.8.2003, n' 193 & Sicily & $n^{\circ} 1491 / 03$ \\
\hline Sardegna & & Sardinia & $\mathrm{n}^{\circ} 148 / 07$ \\
\hline
\end{tabular}

Table 5. Main Italian PDO and IGP extra-virgin olive oils from different regions and legislative references at Italian and European level. ( ${ }^{*}$ Official Journal of Italian Republic; ${ }^{* *}$ Official Journal of European Community) Source: http://www.frantoionline.it/dop-eigp/olio-dop-zone-di-produzione.html 


\begin{tabular}{|l|c|}
\hline & Allele size (bp) \\
\hline Ogliarola Barese & $180-200$ \\
\hline Ogliarola Garganica & $180-190$ \\
\hline Ogliarola Salentina & $180-210$ \\
\hline Ogliarola & $\mathbf{1 8 0}-\mathbf{2 1 0}$ \\
\hline
\end{tabular}

Table 6. Allelic profile for the SSR GAPU89 in the "Ogliarola" cultivars

\begin{tabular}{lcccccc}
\hline SSR marker & \multicolumn{2}{c}{ Cima di Bitonto } & \multicolumn{2}{c}{ Ogliarola barese } & \multicolumn{2}{c}{ Coratina } \\
\hline DCA03 & 237 & 243 & 243 & 256 & 239 & 243 \\
DCA04 & 130 & 132 & 140 & 190 & 130 & 165 \\
DCA18 & 177 & 179 & 177 & 177 & 177 & 181 \\
\hline
\end{tabular}

Table 7. Allelic profile for 3 SSR markers of the 3 olive cultivars comprised in the disciplinary of production of "Terra di Bari", sub-denomination "Bitonto",

line with Baldoni et al. (2009) which reported the SSR DCA04 to have low peak stuttering and strong peak intensity during electrophoresis. The main drawbacks for DCA04 were represented by the $n^{\circ}$ of loci amplified (2) and by a high frequency of null alleles $(>0.05)$. DCA4 was used to amplify DNA from both the leaves and the oils of 5 cultivars: Cellina di Nardò, Coratina, Frantoio, Leccino, Ogliarola barese. Materials and methods on how to extract monovarietal virgin olive oil is reported in this and other here revised papers produced by the DiBCA. In this research, in particular, the authors begun to question the possibility that the full DNA match between the leaves and oil can be undermined by the emergence of different alleles of paternal origin. In fact, if leaf DNA is practically identical to oil DNA since oils derived mainly from olive flesh, that is derived from the evolution of the ovary (e.i. from mother plant), on the other side the contribution of the pollen from the pollinator plant resides in the seed whose oily fraction represents only a minor percentage of the final oil, and whose solid phase is almost totally eliminated during oil processing. It is evident that this problem occurs for self-incompatible cultivars. Thus, before treating as a fraud the incoming of different alleles when a DNA from oil is amplified with SSR and compared to DNA from leaves, one should ask the pollinating nature of the cultivar employed to produce oil, the percentage of allogamy, the presence in the same cultivations areas of other olive cultivars genetically compatible.

Therefore, given the efficiency and speed with which SSR analyses can be conducted on DNA extracted from both leaves and oil, a study of correspondence between genetic profiles obtained from leaves and oil was undertaken at the DiBCA by considering 7 olive cultivars, and 10 SSR (Alba et al., 2009b). The cultivars chosen are all used in different disciplinaries of production of PDO oils. Three $\mathrm{kg}$ of drupes from certified clones were collected and milled to obtain monovarietal oils. DNA was extracted as previously reported, yielding as expected a mean concentration of $100 \mathrm{ng} / \mu \mathrm{l}$ for DNA from leaves and $5 \mathrm{ng} / \mu \mathrm{l}$ from DNA from oil. Six out of 10 SSR gave clear and unequivocal electrophoretic patterns, while 4 SSRs failed to amplify on at least 2 of the 7 cultivars tested, being the Coratina the most difficult to amplify. The research revealed identical patterns between leaves and oil DNA for $90 \%$ of the experiments, even in cases where SSR revealed a multilocus nature. Fig. 4 shows a comparison between oil and leaves electrophoretic patterns of cultivar Leccino obtained with SSR DCA03 and it is evident how peaks for alleles amplified from oil were different in 


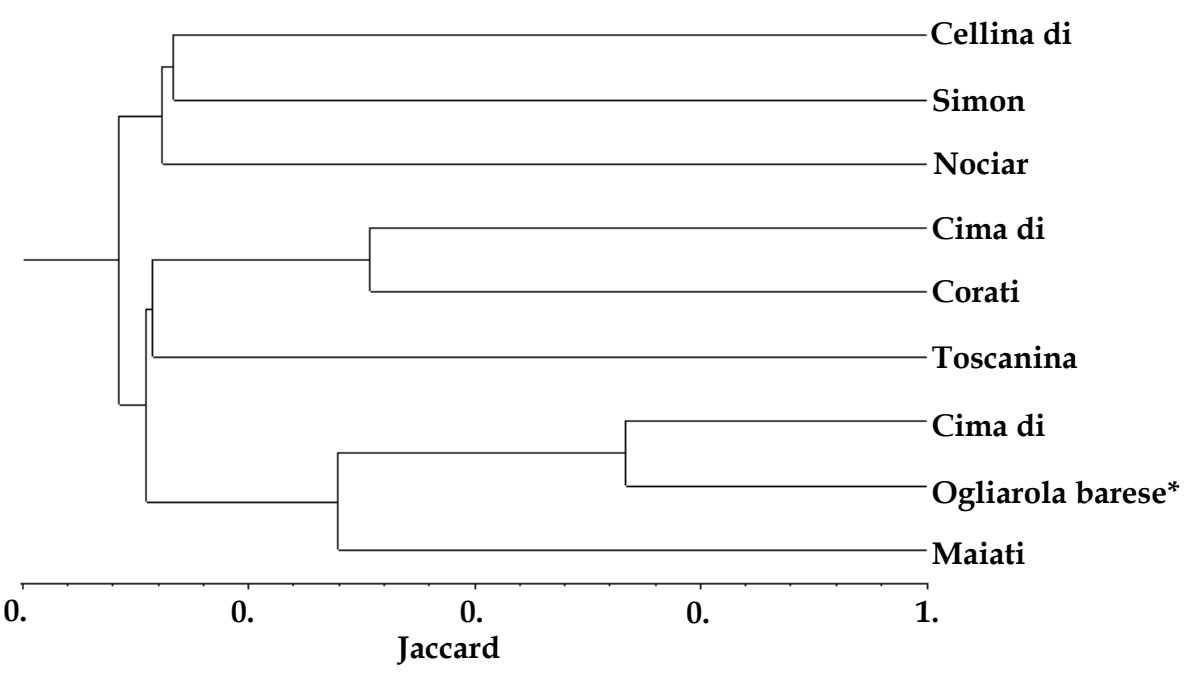

Fig. 2. Dendrogram of genetic similarity based on Jaccard Index of 3 Italian olive cultivars included in the disciplinary of production of "Terra di Bari", sub-denomination "Bitonto", indicated with *, compared to other 6 Italian olive cultivars.
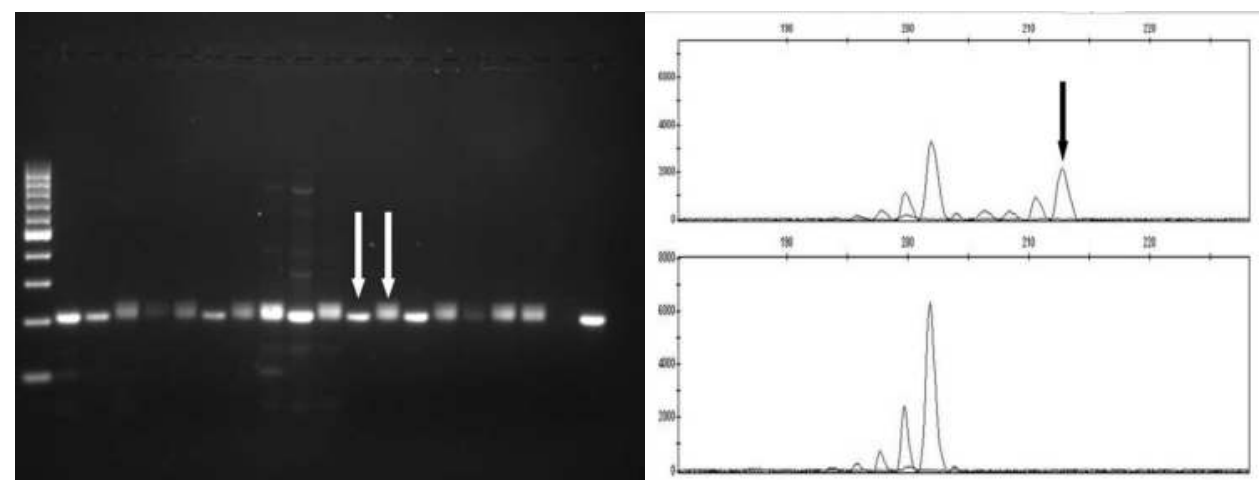

Fig. 3. Comparison of SSR electrophoretic pattern on agarose gel 2\% (left) and on ABI PRISM 3100 Avant Genetic Analyzer (right). Arrows indicate polymorphisms between olive cultivars. The polymorphism revealed by the sequencer is more evident than that revealed by agarose gel.

shape and height but not in molecular weight with respect to alleles from leaves. The reduced height of oil peaks was determined by the lower quality and concentration of template with respect to leaves. In our previous researches cases of a non-complete concordances between leaves and oil DNA did not emerged, probably due to the low resolution of the methods employed to resolve amplifications (agarose, PAGE). In this research the use of a sequencer let to identify some miss-matches between leaves and oil DNA due to the loss or gain of alleles in the oil DNA. The loss of some peaks in oil profiles was hypothesized to be related to the degraded DNA for the process of olive oil extraction, 
to a low signal of the amplicons, or to troublesome working conditions for the polymerase. On the other hand, a wrong denominations of the cultivars or the occurrence of somaclonal mutations as causes of the gain of additional alleles in oil profiles with respect to leaf DNA could be excluded since the certified origin of cultivars and the belonging of leaves and drupes to the same clone. An accredited hypothesis is represented by a paternal contribution of embryos in oil samples extracted from entire drupes, in line with Doveri et al. (2006) that recorded diverse profiles in oil and plant tissues of the cultivar "Leccino", suggesting a nonmaternal origin of additional alleles in oil profiles arisen from out-crossing. A confirmation of the hypothesis of a paternal contribution is offered by the presence of all the scored additional alleles in the electrophoretic profiles of the other cultivars of the research, suggesting, in fact, that out-crosses could be occurred between clones grown in the same field.
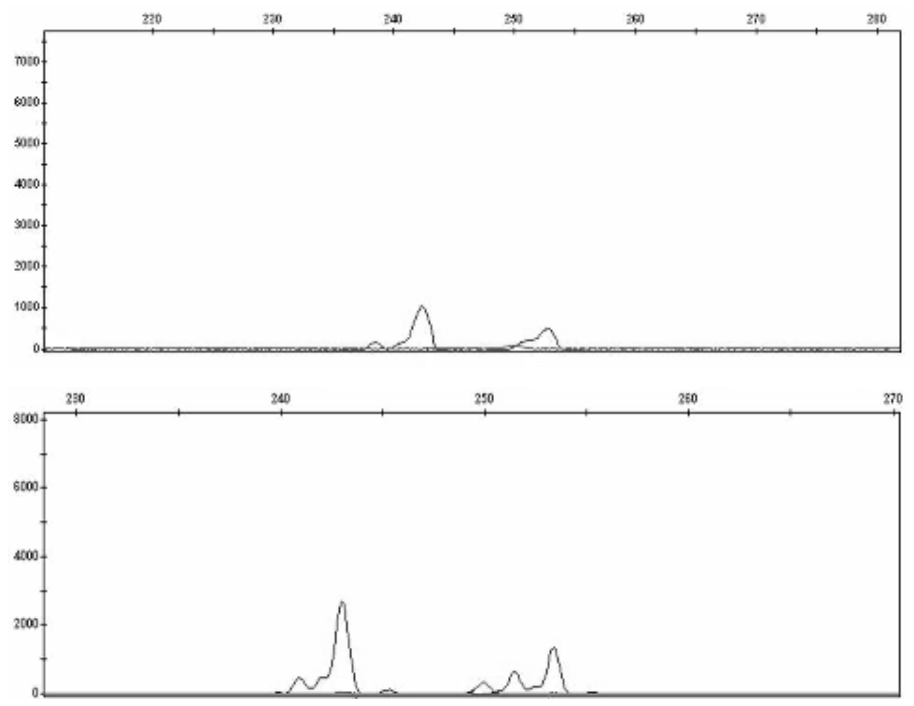

Fig. 4. Electropherograms of Leccino cultivar oil (up) and leaves (down) obtained with SSR DCA03. The reduced height of oil peaks was determined by the lower quality and concentration of template with respect to leaves.

Next, the screening of olive cultivar diversity continued when a total of 30 cultivars was analyzed with 16 SSR (Alba et al., 2009a). A molecular identification key with the minimum number of markers revealed that 2 SSR were able to distinguish all the cultivars. In order to identify the SSR that better respond to this purposes we used two measures of the ability of primers to distinguish between genotypes by calculating Resolving Power (RP) (Prevost \& Wilkinson, 1999) and Power of Discrimination (Kloosterman et al., 1993). RP consists in the use of a function strongly correlated to the proportion of genotypes identified by a certain molecular marker, independently of the number of genotypes composing the collection. PD is calculated by considering in the formula the genotype frequency instead of the allele frequency. A correlation between the number of distinguished cultivars (NDC) and the values of PD and RP of each SSR was estimated. The comparison between the two possible indices of diversity revealed a higher suitability of $\mathrm{PD}$, with respect to $\mathrm{RP}$, to predict the 
ability of SSR marker in distinguishing among genotypes, suggesting that indices based on genotypic frequency are more suitable than those based on allelic frequency. A Principal Component Analysis (PCA) was performed for this review by using SSR profiles (Fig. 5) and computing data to construct a three-dimensional array of eigenvectors by the DCENTER module of the NTSYS-PC program (Rohlf, 1992).

The first Component accounted for $9.8 \%$ of the total allelic variation, while the second for $9.2 \%$ and the third for $6.0 \%$, for a total SSR diversity of $25.0 \%$. This low value suggested that more Components should be considered when representing the PCA and indicated that 16 SSR allowed the screening of a minimal part of the total biodiversity contained by the 30 olive cultivars investigated.

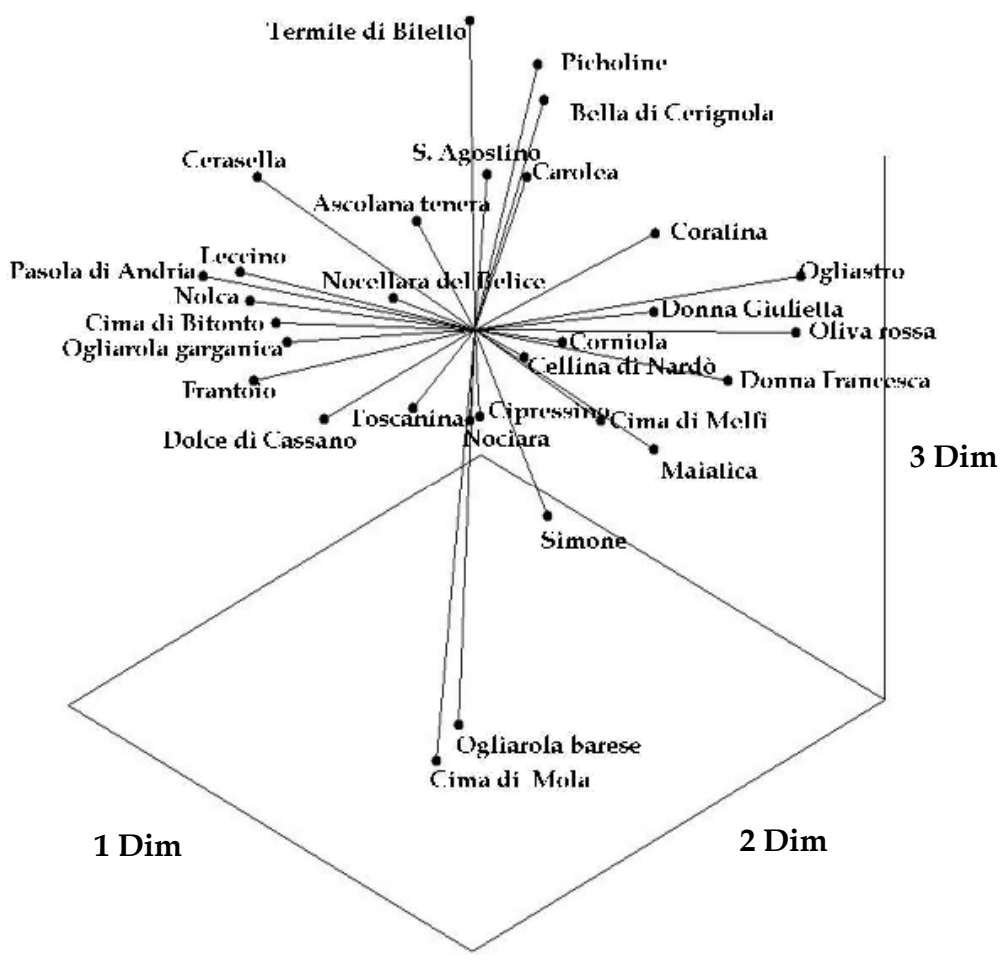

Fig. 5. Principal Component Analysis of 30 Italian olive cultivars analysed with 16 SSRs. Lines represent vectors.

\section{Conclusions}

Molecular markers have become an indispensable tool in plant breeding for both biodiversity studies and quality selection of products. Marker Assisted Selection (MAS) reduces entrie redundancy in germplasm collections, reveals cases of synonymy and homonymy in several crops, let a early selection of interesting lines in breeding programs Several classes of molecular markers (ISSR, AFLP, SSR) were screened on more than 80 olive cultivars of the Mediterranean basin at the DiBCA in approximately 10 years, passing from 
traditional lab protocols laborious, in some cases hazardous and subjected to many environmental variables, and arriving to the use of health-safe reagents and standardized procedures. In this sense, the efficacy and the advantages showed by SSR with respect to ISSR and AFLP is well known. In particular, in olive oil traceability they revealed their ability to amplify highly degraded DNA extracted from oil. SSR generally amplify fragments of 100-300 bp, while ISSR generate amplicons of higher molecular weight (500$2000 \mathrm{bp}$ ) and it can be argued that a degraded DNA from oil works better with short fragments. Furthermore, the step of enzymatic digestion in the AFLP can represent a severe bottleneck when processing degraded oil DNA. For all these reasons, SSR are now widely used for cultivar identification, while more needs to be done for their use in traceability. As an example, most of the PDO oils are multivarietal, so the traceability of a single cultivar becomes hard to be verified. Thus, approaches based on quantitative Real Time PCR can help to correctly define which cultivars are present in a certain oil and in which percentages. Indeed, if the approach is based on qualitative PCR, independently from the class of molecular marker, only monovarietal oils can be traced.

Genomes of several crops and woody species have been completely sequenced and characterized, while few is known about the olive genome. However, the increasing availability of Expressed Sequence Tags (EST) deduced from mRNA extracted from olive and annotated on the web (www.Oleadb.it) represent an interesting starting point for "candidate gene" approach, with the goal of a cultivar characterization based on gene functionality. It cannot be ignored that functional genomics offer the possibility not only to distinguish cultivars merely on restricted genomic areas often harbouring intronic regions, but it let the knowledge of how gene biodiversity in olive can lead to a certain organoleptic oil profile rather than to another.

Actually, the DiBCA is attempting researches on SSR alleles specific for some Southern Italian olive cultivars, while the approach of the "candidate gene" has been enterprised to isolate and characterize genes involved in the Kennedy pathway that leads to the syntesis or desaturation of long chain fatty acids in olive oil. In the future, the complete genome sequencing of olive will offer new opportunities to better understand the evolution, the existing biodiversity and the physiological aspects of a species that fused its hystory with that of mankind all over the Mediterranean basin in the last 5000 years.

\section{Aknowledgments}

This work was conducted within the framework of "Progetto interregionale OLVIVA" funded by Programma Interregionale - "Sviluppo rurale - Innovazione e Ricerca" D.M. n. 25279 of 23/12/03" and of "Progetto Strategico PS59" funded by Regione Puglia, Italy .

\section{References}

Alba, V., Montemurro, C. \& Blanco A. (2008) Valorizzazione dell'olio "Terra di Bari" mediante l'applicazione dei marcatori molecolari microsatellite. Proceedings of the VIII National Congress on Biodiversity - La Biodiversità: Risorsa per Sistemi Multifunzionali, Lecce, Italy, April 21 - 23, pp. 15 - 17.

Alba, V., Montemurro, C., Sabetta, W., Pasqualone, A. \& Blanco, A. (2009a). SSR-based identification key of cultivars of Olea europaea L. diffused in Southern-Italy. Scientia Horticulturae, No. 123, pp. 11-16. 
Alba, V., Sabetta, W., Blanco, A., Pasqualone, A. \& Montemurro, C. (2009b). Microsatellite markers to identify specific alleles in DNA extracted from monovarietal virgin olive oils. European Food Research and Technology, N²29, pp. 375-382.

Angiolillo, A., Mencuccini, M. \& Baldoni, L. (1999). Olive genetic diversity assessed using amplified fragment length polymorphisms. Theoretical and Applied Genetics, No. 98, pp. 411-421.

Baldoni, L., Cultrera, N.G., Mariotti R., Riccioloni, C., Arcioni S., Vendramin, G.G., Buonamici, A., Porceddu, A., Sarri, V., Ojeda, M.A., Trujillo, I., Rallo, L., Belaj, A., Perri, E., Salimonti, A., Muzzalupo, I., Casagrande, A., Lain, O., Messina, R. \& Testolin, R. ( 2009). A consensus list of microsatellite markers for olive genotyping. Molecular Breeding, Vol. 24, No. 3, pp. 213-231.

Belaj, A., Satovic, Z., Cipriani, G., Baldoni, L., Testolin, R., Rallo, L. \& Trujillo, I. (2003). Comparative study of the discriminating capacity of RAPD, AFLP and SSR markers and their effectiveness in establishing genetic relationships in olive. Theoretical and Applied Genetics, No. 107, pp. 736-744.

Bendini, A., Cerretani, L., Carrasco-Pancorbo, A., Gómez-Caravaca, A. M., Segura-Carretero, A., Fernández-Gutiérrez, A. \& Lercker, G. (2007). Phenolic molecules in virgin olive oils: A survey of their sensory properties, health effects, antioxidant activity and analytical methods. An overview of the last decade. Molecules, 12, 1679-1719.

Breton, C., Claux, D., Metton, I., Skorski, G. \& Berville, A. (2004). Comparative study of methods for DNA preparation from olive oil samples to identify cultivar SSR alleles in commercial oil samples: possible forensic applications. Journal of Agricultural and Food Chemistry, No. 52, pp. 531-537.

Carriero, F., Fontanazza, G., Cellini, F. \& Giorio, G. (2002). Identification of simple sequence repeats (SSRs) in olive (Olea europaea L.). Theoretical and Applied Genetics, No. 104, pp. 301-307.

Catalano, P. \& Caponio, F. (1996). Machines for olive paste preparation producing quality virgin olive oil. Fett/Lipid, No. 98, pp. 408-412.

Cipriani, G., Marrazzo, M.T., Marconi, R., Cimato, A. \& Testolin, R. (2002). Microsatellite markers isolated in olive (Olea europaea L.) are suitable for individual fingerprinting and reveal polymorphism within ancient cultivars. Theoretical and Applied Genetics, No. 104, pp. 223-228.

Commission Regulation (EU) No 61/2011 of 24 January 2011 amending Regulation (EEC) No 2568/91 on the characteristics of olive oil and olive-residue oil and on the relevant methods of analysis. Official Journal of the European Union L23 of 27.01.2011, pp. 1-14.

Consolandi, C., Palmieri, L., Severgnini, M., Maestri, E., Marmiroli, N., Agrimonti, C., Baldoni, L., Donini. P., De Bellis, G. \& Castiglioni, B. (2008). A procedure for olive traceability and authenticvity: DNA extraction, multiplex PCR and LDR-universal array analysis. European Food Research E Technology, No. 227, pp. 1429-1438.

Corrado, G., La Mura, M., Ambrosino, O., Pugliano, G., Varricchio, P. \& Rao R. (2009). Relationship of Campanian olive cultivars: comparative analysis of molecular and phenotypic data. Genome, No. 52, pp. 692-700.

De la Rosa, C., James, M. \& Tobutt, K.R. (2002). Isolation and characterization of polymorphic microsatellites in olive (Olea europaea L.) and their transferability to other genera in the Oleaceae. Molecular Ecology Notes, No. 2, pp. 265-267.

de la Torre, F., Bautista, R., Ca'novas, F. \& Claros, G. (2004). Isolation of DNA from olive oil and oil sediments: application in oil fingerprinting. Food, Agriculture E Environment, Vol 2, No. 1, pp. 84-89. 
Diaz, A., De la Rosa, R.,Martin, A. \& Rallo, P. (2006). Development, characterization and inheritance of new microsatellites in olive (Olea europaea L.) and evaluation of their usefulness in cultivar identification and genetic relationship studies. Tree Genetics $\mathcal{E}$ Genomes, No. 2, pp. 165-175.

Doveri, S., O'Sullivan, D.M. \& Lee, D. (2006). Non-concordance of genetic profiles between olive oil and fruit: a cautionary note to the use of DNA markers in provenance testing. Journal of Agricultural and Food Chemistry, No. 54, pp. 9921-9926.

Ganino, T., Bartolini, G., \& Fabbri, A., (2006) The classification of olive germplasm-a review. Journal of Horticoltural Science and Biotechnology, Vol. 81, No. 3, pp. 319-334.

Grati-Kamoun, N., Lamy Mahmoud F., Reba1, A., Gargouri, A., Panaud, O. \& Saar, A. (2006). Genetic diversity of Tunisian olive tree (Olea europaea L.) cultivars assessed by AFLP markers. Genetic Resources and Crop Evolution, No. 53, pp 265-275.

Harwood, J. L. \& Yaqoob, P. (2002). Nutritional and health aspects of olive oil. European Journal of Lipid Science and Technology, 104, 685-697. http:/ / faostat.fao.org/site/567/default.aspx\#ancor

Istat, Istituto di Statistica Italiana, (2010). Tav. C27. Available from <http://agri.istat.it/sag_is_pdwout/jsp/consultazioneDati.jsp>

Jaccard, P. (1901). Etude comparative de la distribution florale dans une portion des Alpes et des Jura. Bulletin de la Société Vaudoise des Sciences Naturelles, No. 37, pp. 547-579.

Kloosterman, A.D., Budowle, B. \& Daselaar, P. (1993). PCR amplification and detection of the human D1S80 VNTR locus. Amplification conditions, population genetics and application forensic analysis. International Journal of Legal Medicine, No. 105, pp. 257-264.

Loukas, M. \& Krimbas, C.B. (1983). History of olive cultivars based on their genetic distances. Journal of Horticultural Science, No. 58, pp. 121-127.

Montemurro, C., Pasqualone, A., Simeone, R., Sabetta W. \& Blanco A. (2008a). AFLP molecular markers to identify virgin olive oils from single Italian cultivars. European Food Research and Technology, No. 226, pp. 1439-1444.

Montemurro, C., Simeone, R., Blanco A., Saponari, M., Bottalico, G., Savino, V., Martelli, G.P. \& Pasqualone, A. (2008b) Sanitary selection and molecular characterization of olive cultivars grown in Apulia. Acta Horticulturae, No. 791, pp. 603-609.

Montemurro, C., Simeone, R., Pasqualone, A., Ferrara, E. \& Blanco, A. (2005). Genetic relationships and cultivar identification among 112 olive accessions using AFLP and SSR markersJournal of Horticultural Science E Biotechnology, Vol. 80, No. 1, pp. 105-110.

Official Journal of the European Communities. Commission Regulation (EC) No 1263/1996 of 1 July 1996 supplementing the Annex to Regulation (EC) No. 1107/96 on the registration of geographical indications and designations of origin under the procedure laid down in Article 17 of Regulation (EEC) No 2081/92. Official Journal European Community, 1996, L163, pp. 19-21.

Official Journal of the Italian Republic. Ministero per il Coordinamento delle Politiche Agricole, Alimentari e Forestali. Decreto Ministeriale 4 novembre 1993, n. 573. Regolamento recante norme di attuazione della legge 5 febbraio 1992, n. 169, per la disciplina del riconoscimento delle denominazioni di origine, dell'albo degli oliveti, della denuncia di produzione delle olive e dell'attività delle commissioni di degustazione degli oli a denominazione di origine controllata. Official Journal Italian Republic , 1994, 3, pp. 1-14.

Official Journal of the Italian Republic. Ministero per le Politiche Agricole. Decreto 29 settembre 1998. Approvazione del disciplinare di produzione della denominazione 
di origine controllata dell'olio extravergine di oliva "Collina di Brindisi". Official Journal Italian Republic, 1998, 250, pp. 43-45.

Pasqualone, A., Caponio, F. \& Blanco, A. (2001). Inter-simple sequence repeat DNA markers for identification of drupes from different Olea europaea L. cultivars. European Food Resesearch Technology, No 213, pp. 240-243.

Pasqualone, A., Montemurro C., Caponio, F. \& Blanco, A. (2004a). Identification of virgin olive oil from different cultivars by analysis of DNA microsatellites. Journal of Agricultural and Food Chemistry, No 52, pp. 1068-1071.

Pasqualone, A., Montemurro C., Caponio, F. \& Simeone R. (2003). Multiplex amplification of DNA microsatellite markers to fingerprint olive oils from single cultivars. Polish Journal of Food and Nutrition Science, No. 12/53, pp. 96-99.

Pasqualone, A., Montemurro C., Caponio, F., Simeone R. \& Blanco, A. (2004b). Analisi del DNA in oli di oliva vergini monovarietali mediante marcatori microsatelliti: fattori limitanti dovuti alla tecnologia produttiva. La Rivista Italiana delle Sostanze Grasse, No. 81, pp. 221-224.

Pasqualone, A., Montemurro, C., Ashtar, S., Caponio, F., Ferrara, E., Saponari, M., Ibrahem, A. AL, Rahman Kalhout, A. \& Blanco, A. (2007b). Set up of a DNA bank of Olea europaea L. the objective being cultivar traceability in olive oil. Proceedungs of the $3^{\text {rd }}$ CIGR International Symposium, Section VI - Food and agricultural products: processing and innovations, Naples, Italy, September 24-26. Published on La Rivista Italiana delle Sostanze Grasse, (2008), No 85, pp. 83-91.

Pasqualone, A., Montemurro, C., Summo, C., Sabetta, W., Caponio, F. \& Blanco A. (2007a). Effectiveness of microsatellite DNA markers in checking the identity of Protected Designation of Origin extra virgin olive oil. Journal of Agricultural and Food Chemistry, No 55, pp. 3857-3862.

Powell, W., Morgante, M., Andre, C., Hanafey, M., Vogel, J., Tingey, S. \& Rafalski, A. (1996). The utility of RFLP, RAPD, AFLP and SSRP (microsatellite) markers for germplasm analysis. Molecular Breeding, No. 2, pp. 225-238.

Prevost, A. \& Wilkinson, M.J. (1999). A new system of comparing PCR primers applied to ISSR fingerprinting. Theoretical and Applied Genetics, No. 98, pp. 107-112.

Rohlf, F.J. (1992). Numerical taxonomy and multivariate analysis system version 1.70. State University of New York, Stony Brook N.Y.

Russell, J.R., Fuller, J.D., Macaulay, M., Hatz, B.G., Jahoor, A., Powell, W. \& Waugh, R. (1997). Direct comparison of level of genetic variation among barley accessions detected by RFLPs, AFLPs, SSRs and RAPDs. Theoretical and Applied Genetics, No. 95, pp. 714-22.

Sefc, K.M., Lopes, M.S., Mendonca, D., Rodrigues Dos Santos, M., Laimer Da Camara Machado, M. \& Da Camara Machado, A. (2000). Identification of microsatellite loci in olive (Olea europaea) and their characterization in Italian and Iberian olive trees. Molecular Ecology, No. 9, pp. 1171-1173.

Sensi, E., Vignai, R., Scali, M., Masi, E. \& Cresti, M. (2003). DNA fingerprinting and genetic relatedness among cultivated varieties of Olea europaea L. estimated by AFLP analysis. Scientia Horticulturae, No. 97, pp. 379-388.

Sharp, P.J., Kreis, M., Shewry, P.R \& Gale, M.D. (1988). Location of $\beta$-amylase sequences in wheat and its relatives. Theoretical and Applied Genetics, No. 75, pp. 286-290.

Visioli, F., Poli, A. \& Galli, C. (2002). Antioxidant and other biological activities of phenols from olives and olive oil. Medicinal Research Reviews, 22, 65-75.

Vos, P., Hogers, R., Bleeker, M., Reijans, M., Van De Lee, T., Hornes, M., Frijters, A., Pot, J., Peleman, J., Kuiper, M. \& Zabeau, M. (1995). AFLP: a new technique for DNA fingerprinting. Nucleic Acids Research, No. 23, pp. 4407-4414. 


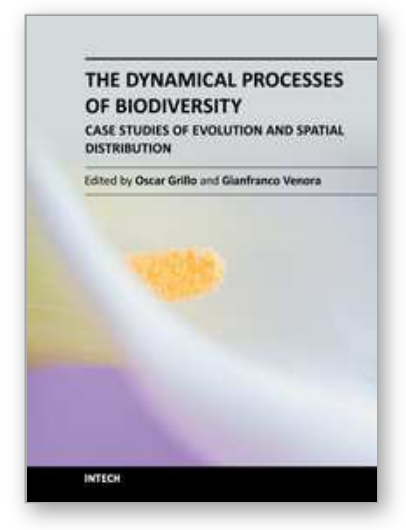

\author{
The Dynamical Processes of Biodiversity - Case Studies of \\ Evolution and Spatial Distribution \\ Edited by PhD. Oscar Grillo
}

ISBN 978-953-307-772-7

Hard cover, 366 pages

Publisher InTech

Published online 02, December, 2011

Published in print edition December, 2011

Driven by the increasing necessity to define the biological diversity frame of widespread, endemic and threatened species, as well as by the stimulating chance to describe new species, the study of the evolutive and spatial dynamics is in constant execution. Systematic overviews, biogeographic and phylogenic backgrounds, species composition and distribution in restricted areas are focal topics of the 15 interesting independent chapters collected in this book, chosen to offer to the reader an overall view of the present condition in which our planet is.

\title{
How to reference
}

In order to correctly reference this scholarly work, feel free to copy and paste the following:

V. Alba, W. Sabetta, C. Summo, F. Caponio, R. Simeone, A. Blanco, A. Pasqualone and C. Montemurro (2011). Olive (Olea Europaea L.): Southern-Italian Biodiversity Assessment and Traceability of Processed Products by Means of Molecular Markers, The Dynamical Processes of Biodiversity - Case Studies of Evolution and Spatial Distribution, PhD. Oscar Grillo (Ed.), ISBN: 978-953-307-772-7, InTech, Available from: http://www.intechopen.com/books/the-dynamical-processes-of-biodiversity-case-studies-of-evolution-andspatial-distribution/olive-olea-europaea-I-southern-italian-biodiversity-assessment-and-traceability-ofprocessed-product

\section{INTECH}

open science | open minds

\author{
InTech Europe \\ University Campus STeP Ri \\ Slavka Krautzeka 83/A \\ 51000 Rijeka, Croatia \\ Phone: +385 (51) 770447 \\ Fax: +385 (51) 686166 \\ www.intechopen.com
}

\author{
InTech China \\ Unit 405, Office Block, Hotel Equatorial Shanghai \\ No.65, Yan An Road (West), Shanghai, 200040, China \\ 中国上海市延安西路65号上海国际贵都大饭店办公楼 405 单元 \\ Phone: +86-21-62489820 \\ Fax: +86-21-62489821
}


(C) 2011 The Author(s). Licensee IntechOpen. This is an open access article distributed under the terms of the Creative Commons Attribution 3.0 License, which permits unrestricted use, distribution, and reproduction in any medium, provided the original work is properly cited. 